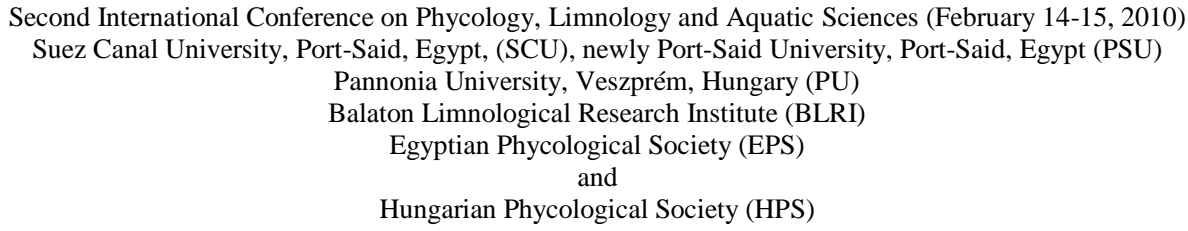

\title{
BIOINDICATION OF WATER POLLUTION IN THE SOMES RIVER USING BIOCHEMICAL AND PHYSIOLOGICAL PARAMETERS OF THE GREEN
} ALGA SCENEDESMUS OPOLIENSIS P. RICHTER

\author{
Laszlo Fodorpataki; Zsolt Gy. Keresztes; Csaba Bartha and Szabolcs \\ Barna \\ “Babes-Bolyai” University, Dept. Biology, RO-400084 Cluj-Napoca, 1 \\ Kogalniceanu St.
}

\begin{abstract}
Cultures of Scenedesmus opoliensis P. Richter, used as single-species test systems, were exposed to differently polluted water samples collected from distinct sectors of the Somes River, in order to identify physiological and biochemical markers suitable for a reliable bioindication of changes in the quality of aquatic environments. Algal cultures grown in Bold's basal nutrient medium were used as control, and another reference consisted of cultures exposed to $25 \mu \mathrm{M} \mathrm{CdCl}_{2}$. Environmental stress exerted by water pollution induced changes in the antioxidative protection of algal cells. When only small amounts of hydrogen peroxide were generated, the activities of ascorbate peroxidase and of superoxide dismutase were enhanced, while the activity of these enzymes declined when hydrogen peroxide accumulated in cells. Vitamin C content of algal cells increased moderately, but significantly under water pollution. The chlorophylls to carotenoids ratio and net oxygen production decreased, while membrane lipid peroxidation increased in polluted water. Cell density was more affected than dry biomass. From among the parameters of induced chlorophyll fluorescence, potential quantum efficiency and vitality index exhibited the most sensitive changes in accordance with the pollution of aquatic environment. The above mentioned parameters of Scenedesmus opoliensis may be useful biochemical and physiological markers of water pollution.
\end{abstract}

Keywords: Antioxidants, Chlorophyll Fluorescence, Lipid Peroxidation, Monoalgal Culture, Polluted Water, Stress Tolerance, Vitality Index

\section{Introduction}

Rivers that cross urban and industrial areas contain fluctuating amounts of various inorganic and organic pollutants. Studies on the influence of pollutants on 
aquatic organisms involve standardized single-species test systems. Microalgae are highly suitable for ecotoxicological tests, but one has to identify those physiological and biochemical parameters which are good markers for a sensitive, reliable and cost-efficient bioindication of water quality (Kaplan, 2007). The Somes River is one of the main tributaries of the Tisa and Danube rivers in Eastern Europe. It has two main branches; one collects its water from the Eastern Carpathians, while the other originates from more springs in the Western Carpathians. Along its course the river passes through several Transylvanian cities, industrial, agricultural and mining areas. Thorough investigations of the ecological status of this river revealed the main sources of anthropogenic pollution, and registered chemical changes that challenge the adaptive capacity of different aquatic communities. The complexity and diversity of environmental impact of water pollution needs further and more specific studies on how different types of organisms react to changes in water quality, with the final aim of developing a complex biomonitoring system (Sarkany-Kiss and Hamar, 1999).

The main reason for including algae in environmental monitoring programs is their key role in mediating the flux of energy and nutrient availability in aquatic ecosystems. Algal indicators can be used in all aquatic habitats and for a wide range of environmental stressors. Individual species are generally widely distributed among ecosystems and geographical regions, and this widespread occurrence reduces problems associated with standardizing metrics. Because of their short response times, algae often provide one of the first signals of aquatic ecosystem impacts, but the same attributes that allow algae to react rapidly to anthropogenic stressors also makes them susceptible to fluctuations in environmental conditions unrelated to human impact (Kaplan, 2007).

At present, a sustained effort of scientists is focusing on identification of molecular and physiological markers for specific stress reactions of different organisms exposed to various environmental constrains. Due to the high diversity of species and of stress factors in different habitats, no generally applicable marker was found yet which would be suitable for bioindicating the impact of environmental changes on metabolic and developmental processes that determine acclimation of individuals and adaptation of populations to polluting agents (Reavie et al., 2010). Ecophysiological and biochemical investigations allow an insight into the intimate mechanisms of action of the environmental stress factors on basic biological processes such as photosynthesis, reproduction, induced metabolic reactions. These parameters not only reflect how different organisms cope with extreme conditions, but also indicate significant changes in the quality of the environment (Prado et al., 2009). Ecotoxicological studies performed with different species of green microalgae refer mainly to the metabolic changes induced by pollution of water with different herbicides and heavy metals, administrated separately or in different combinations (Geoffroy et al., 2002; Zbigniew and Wojciech, 2006; Perales-Vela et al., 2007; Fodorpataki et al., 
2009). Metabolic changes induced in algae by chemical stressors are important not only for bioindicating water quality, but also for designing efficient wastewater treatment systems, for protection of endangered aquatic habitats, as well as for use of algal biomass in aquaculture and as a dietary supplement (Lombardi et al., 2005; Celekli et al., 2008; Rodriguez-Garcia and GuilGuerrero, 2008; Zhang et al., 2008). Metabolic and developmental reactions to different stress factors vary greatly not only between species, but also between different ecotypes and varieties of the same algal species (Gorbi $\boldsymbol{e t}$ al., 2006). In this context, identification of reliable biochemical markers of stress reactions is important in biomonitoring early responses of organisms to pollution, in order to be able to act promptly for the protection of endangered habitats.

The aim of this work is to identify sensitive physiological and biochemical parameters of the green microalga Scenedesmus opoliensis, suitable for bioindication of changes in the quality of aquatic environments. Standardized ecotoxicological tests relying on these biomarkers may be applied to detect degradation of water quality in rivers with different sources of pollution along the different sectors.

\section{Materials and Methods}

Axenic monoalgal cultures of the green microalga Scenedesmus opoliensis P. Richter (Chlorophyceae), strain AICB 141, originating from an unpolluted freshwater pond of the Somes River basin and kept in the algal culture collection of the Biological Research Institute in Cluj-Napoca (Dragos $\boldsymbol{e t}$ al., 1997) were grown in Bold's basal nutrient medium (Lee and Shen, 2007). In the stage of exponential population growth, aliquots from these cultures were inoculated in water samples collected from different sectors of the Somes River. Water samples were sterilized by filtration through Millipore membrane filter with pore diameter of $0.22 \mu \mathrm{m}$, in order to exclude microorganisms. One liter of water was collected from each sampling site, then it was distributed in five culture vessels, and each was inoculated with $20 \mathrm{ml}$ of algal culture. Control cultures were grown in Bold's basal medium. Another reference consisted of cultures exposed to $25 \mu \mathrm{M} \mathrm{CdCl}_{2}$, in order to be able to compare the stress conditions exerted by water samples with the influence of a known polluting substance. The initial cell density of all cultures was adjusted to $2 \times 10^{6}$ cells per milliliter. Water samples were collected from four sites along the Somes River. One sampling site was chosen upstream the city of Cluj, in a mountain region where anthropogenic pollution is considered insignificant. Another sampling site occurred downstream to the city of Cluj, where the water is overloaded with organic matter from communal and industrial wastewater. A third sampling site was selected downstream the town of Dej, where water is overcharged with organic matter and with byproducts of a paper factory. The forth site was near the town of Baia Mare (at Pomi), where water is highly polluted mainly with heavy metals discharged from mines and ore-processing factories (Sarkany-Kiss and Hamar, 1999; 
Cordos et al., 2003). All experimental setups were made in 5 repetitions. Cultures were kept in a growth chamber for 5 days, under a constant illumination with a photon flux density of $95 \mu \mathrm{M} \mathrm{m}^{-2} \mathrm{~s}^{-1}$, at $22{ }^{\circ} \mathrm{C}$, being placed on an orbital shaker (150 rpm).

Parameters of induced chlorophyll $a$ fluorescence were measured with a pulse amplitude modulated chlorophyll fluorometer (PAM-FMS2, Hansatech). Algae were collected by low pressure filtration, providing a uniform layer of cells on a $13 \mathrm{~mm}$ glass fiber filter. Samples were dark adapted for $5 \mathrm{~min}$. The modulated light was sufficiently weak $\left(0.04 \mu \mathrm{M} \mathrm{m}^{-2} \mathrm{~s}^{-1}\right)$ so as not to produce any significant variable fluorescence. A single saturating flash $\left(2000 \mu \mathrm{M} \mathrm{m}^{-2} \mathrm{~s}^{-1}\right.$ for 0.5 s) was applied to reach the maximal fluorescence Fm. After the decline of the signal, the actinic light was turned on $\left(100 \mu \mathrm{M} \mathrm{m}^{-2} \mathrm{~s}^{-1}\right)$ to start the induction kinetics. The determined parameters were initial fluorescence $\mathrm{F}_{0}$, maximal fluorescence $\mathrm{Fm}$, the $\mathrm{Fv} / \mathrm{Fm}$ ratio ( $\mathrm{Fv}$ or variable fluorescence being the difference between the maximal and the initial fluorescence), the $\mathrm{F}_{0} / \mathrm{Fv}$ ratio, modulated maximal fluorescence Fm', steady state fluorescence Fs, the effective quantum use efficiency $(\Phi)$ representing the ratio (Fm' $-\mathrm{Fs}) / \mathrm{Fm}$ ', as well as the vitality index (Rfd) expressed as the ratio $(\mathrm{Fm}-\mathrm{Fs}) / \mathrm{Fs}$ (Mallich and Mohn, 2003; Fodorpataki and Bartha, 2008).

Extraction of photosynthetic pigments was performed in darkness with methanol. $25 \mathrm{ml}$ of algal cell suspension was collected on acid fiber filter, transferred to a centrifuge tube with $5 \mathrm{ml}$ methanol and heated for $10 \mathrm{~min}$. The extracts were centrifuged for $5 \mathrm{~min}$. at $4000 \mathrm{rpm}$, and the supernatant was used for measurement of optical density at $470 \mathrm{~nm}, 653 \mathrm{~nm}$ and $666 \mathrm{~nm}$. Chlorophyll $a$, chlorophyll $b$ and carotenoid pigments were determined spectrophotometrically, according to the equations of Lichtenthaler and Wellburn (1983).

Oxygen production was measured with a Clark type oxygen electrode in an Oxy-Lab chamber (Hansatech) at $22{ }^{\circ} \mathrm{C}$ and $90 \mu \mathrm{M} \mathrm{m}^{-2} \mathrm{~s}^{-1}$ of photosynthetically active radiation. Measurements were made with algal cultures adjusted to an optical density of 0.400 at $680 \mathrm{~nm}$ (Perales-Vela et al., 2007). Cell density of algal cultures was determined citometrically under the light microscope, in the same period of each day. Final dry biomass was determined by filtering $100 \mathrm{ml}$ of each culture, and drying the cell mass at $80{ }^{\circ} \mathrm{C}$ for 48 hours, until a constant dry weight was reached (Fodorpataki et al., 2001).

For determination of lipid peroxidation, algal cultures were centrifuged at $2500 \mathrm{~g}$ for 10 minutes and pellets were weighed. To each pellet $0.1 \%(\mathrm{w} / \mathrm{v})$ trichloroacetic acid was added in $1: 3(\mathrm{~g} / \mathrm{ml})$ ratios. Algae were disintegrated in a cell disrupter, than the extracts were centrifuged at $6300 \mathrm{~g}$ for 10 minutes at $10^{\circ} \mathrm{C}$. $0.5 \%(\mathrm{w} / \mathrm{v}) 2$-thiobarbituric acid solution in $20 \%(\mathrm{w} / \mathrm{v})$ trichloroacetic acid was added to the harvested supernatants in the ratio 1:4 (v/v). The extracts were heated for 45 minutes at $96{ }^{\circ} \mathrm{C}$, and then they were cooled for 10 minutes in ice and 
centrifuged for 10 minutes at $6300 \mathrm{~g}$ and $10{ }^{\circ} \mathrm{C}$. Determination of lipid peroxidation products designated as thiobarbituric acid-reactive substances (consisting mostly in malondialdehyde) was performed photometrically on the supernatants, by measuring their absorbance at $532 \mathrm{~nm}$ and $600 \mathrm{~nm}$ and substracting $\mathrm{A}_{600}$ from $\mathrm{A}_{532}$. For calculation of the concentration of lipid peroxidation products, the extinction coefficient of $155 \mathrm{mM}^{-1} \mathrm{~cm}^{-1}$ was used (Baryla et al., 2000; Gorbi et al., 2006).

Hydrogen peroxide content of algal cells was determined spectrophotometrically. The pellets of centrifuged algal cultures were resuspended in $50 \mathrm{mM}$ potassium phosphate buffer $\mathrm{pH} 6.5$ in a ratio of $1: 32(\mathrm{w} / \mathrm{v})$, and centrifuged at $10000 \mathrm{~g}$ for 25 minutes. The supernatant was mixed with $1 \%$ titanium chloride (in concentrated chlorhydric acid) and centrifuged for 15 minutes at $10000 \mathrm{~g}$. The absorbance of the supernatant was measured at $410 \mathrm{~nm}$, and the $\mathrm{H}_{2} \mathrm{O}_{2}$ content was calculated using the extraction coefficient $0.28 \mu \mathrm{M}^{-1}$ $\mathrm{cm}^{-1}$ (Madhava Rao and Sresty, 2000).

Ascorbic acid (vitamin C) content of the algal cells was determined titrimetrically. $25 \mathrm{ml}$ of each algal suspension was centrifuged at $2500 \mathrm{~g}$ for 10 minutes, the pellet was resuspended in $10 \mathrm{ml}$ of $5 \%(\mathrm{v} / \mathrm{v})$ metaphosphoric acid, filtered and completed with $20 \mathrm{ml}$ of $5 \%$ metaphosphoric acid. This extract was titrated with $0.025 \%$ (w/v) 2,6-dichlorophenol indophenol, until a persistent light pink color appeared. Ascorbic acid content was determined with the help of a standard curve obtained with titration of known concentrations of ascorbic acid (Fodorpataki et al., 2009).

Ascorbate peroxidase enzyme activity was determined in algal cultures that were first centrifuged at $2000 \mathrm{~g}$ for 10 minutes, and then the pellets were ground in $1 \mathrm{~g}$ quartz sand on ice, using a mortar and pestle. Proteins were extracted with $1.5 \mathrm{ml}$ of $0.1 \mathrm{M}$ sodium phosphate buffer $(\mathrm{pH} 7.0)$ and the extract was centrifuged for 20 minutes at $2300 \mathrm{~g}$ and $5{ }^{\circ} \mathrm{C}$. Protein content (as reference for enzyme activity) was determined by the Bradford method, with bovine serum albumin as a standard. Ascorbate peroxidase activity was determined spectrophotometrically, based on the absorption at $270 \mathrm{~nm}$ of a $5 \mathrm{ml}$ final volume of reaction mixture consisting of $1 \mathrm{ml}$ algal extract as enzyme source, $3.5 \mathrm{ml}$ of 50 $\mathrm{mM}$ sodium phosphate buffer ( $\mathrm{pH} 7.5), 0.25 \mathrm{ml}$ of $40 \mathrm{mM}$ sodium ascorbate and $0.25 \mathrm{ml}$ of $200 \mathrm{mM}$ hydrogen peroxide (Geoffroy et al., 2002; ZavaletaMancera et al., 2005).

Enzymatic activity of superoxide dismutase was determined spectrophotometrically in algal extracts obtained in the same way as for the above-described ascorbate peroxidase activity. The cells sedimented from the algal cultures were resuspended in $0.05 \mathrm{M}$ potassium phosphate buffer ( $\mathrm{pH} 7.8$ ). Superoxide dismutase activity was assayed by a method based on inhibition of nitroblue tetrazolium reduction. The reaction mixture contained $2.4 \mu \mathrm{M}$ 
riboflavin, $0.01 \mathrm{M}$ methionine and $1.67 \mu \mathrm{M}$ nitroblue tetrazolium in $0.05 \mathrm{M}$ potassium phosphate buffer $\mathrm{pH} 7.8 .2 .5 \mathrm{ml}$ of this reaction mixture and $0.5 \mathrm{ml}$ of algal extract were mixed and illuminated in glass tubes for 10 minutes with white fluorescent light with a photon flux density of $240 \mu \mathrm{M} \mathrm{m}^{-2} \mathrm{~s}^{-1}$. The absorbance of the illuminated reaction mixture and that of a control represented by potassium phosphate buffer was measured at $560 \mathrm{~nm}$. The superoxide dismutase unit was defined as the amount that causes 50\% inhibition of nitroblue tetrazolium reduction, and enzyme units were expressed per $1 \mathrm{mg}$ of protein $(\mathbf{L i}$ et al., 2005; Zbigniew and Wojciech, 2006).

Each determination was made with 5 replicates, and then the means and standard errors were calculated. In data sets with normal distribution, significant differences between treatment means were determined using the post-ANOVA multiple comparison Tukey test, while in data sets with non-normal distribution, significant differences between means were established with the Kruskal-Wallis test followed by the Mann-Whitney U-test.

\section{Results and Discussion}

Metabolic reactions of the alga Scenedesmus opoliensis exposed to polluted water offer many functional parameters that exhibit different degrees of sensitivity to stress conditions. The most sensitive changes in photosynthetic efficiency, in antioxidative defense and in population growth are valuable physiological and biochemical markers that contribute to a better understanding of stress acclimation and to a more efficient bioindication of complex changes in the quality of aquatic environments.

In vivo induced chlorophyll fluorescence is a sensitive, non-destructive tool for the study of environmental impacts on the primary energy-conversion processes of photosynthesis, on which the entire primary biomass production relies. From the different parameters of induced, non-modulated and pulse amplification modulated chlorophyll fluorescence, we have selected only those which exhibited high variations after the contact of algae with differently polluted water samples taken from distinct sectors of the Somes River. The potential quantum use efficiency of photosynthesis, reflected by the Fv/Fm ratio, exhibited a sensitive decrease especially when the algae came in contact with water polluted with heavy metals originating from the mining area of Baia Mare (Figure 1). This reduction in $\mathrm{Fv} / \mathrm{Fm}$ was even more pronounced than in the algal cultures treated with $25 \mu \mathrm{M}$ of cadmium (without polluted water). The results indicate that severe water pollution, especially when dissolved heavy metals are present, can be detected by determining the $\mathrm{Fv} / \mathrm{Fm}$ ratio in the dark-preadapted algal cultures. Decrease of this value is directly related to the disturbed photochemical reactions that occur in photosystem II of thylakoid membranes in chloroplast, leading to a less efficient photosynthetic use of the absorbed light energy. In studies concerning the influence of five heavy metals on the alga Scenedesmus obliquus, 
Mallich and Mohn (2003) concluded that among the chlorophyll fluorescence characteristics, the $\mathrm{F}_{0} / \mathrm{Fv}$ ratio showed the highest sensitivity to heavy metal pollution, thus indicating that the water-splitting complex of the photosynthetic apparatus is the primary site of action for heavy metals. In our experiments the $\mathrm{F}_{0} / \mathrm{Fv}$ ratio exhibited big variations between the five repetitions of the same experimental setup, and because of this, the differences between polluted water samples and control were statistically not significant. This was also the case of the relative photosynthetic electron transport rate, derived from chlorophyll fluorescence (data not shown), a parameter which was found by Perales-Vela $\boldsymbol{e t}$ al. (2007) to be very useful in detecting stress reactions of Scenedesmus incrassatulus to sub-lethal concentrations of copper.

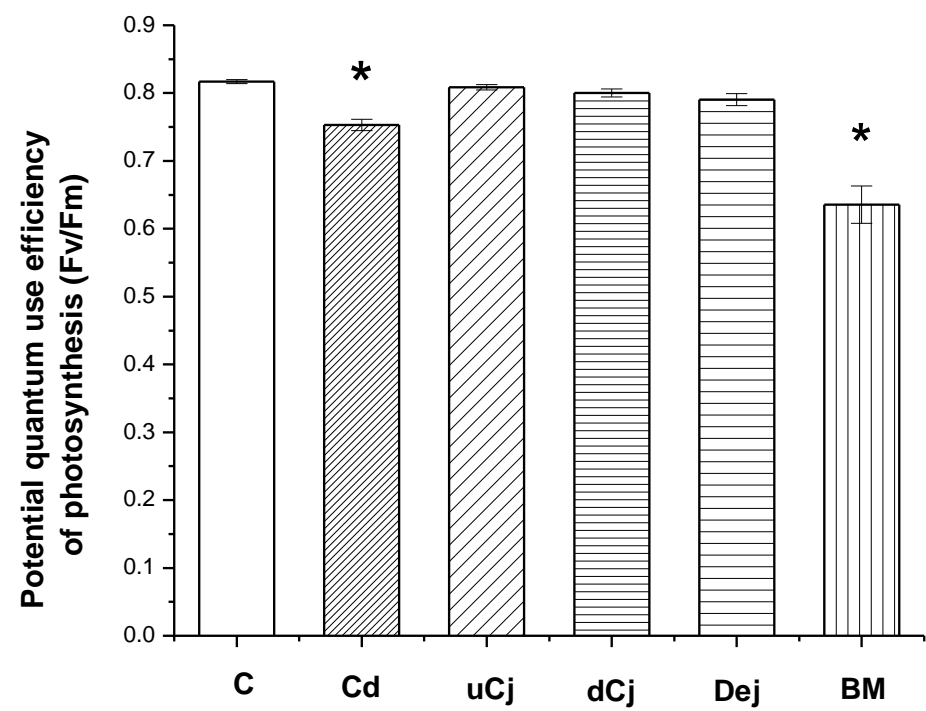

Figure (1): Potential quantum use efficiency of photosynthesis $(\mathbf{F v} / \mathbf{F m})$ in Scenedesmus opoliensis exposed to polluted water samples. C - control; Cd $-25 \mu \mathrm{M}$ $\mathrm{CdCl}_{2}$ in the nutrient medium; $\mathbf{u C j}$ - water from Somes River upstream Cluj city; $\mathrm{dCj}$ - water from downstream Cluj city; Dej - Somes water from the town of Dej; BM - water of Somes River from the Baia Mare region. Bars represent standard errors from means $(n=5)$, asterisk indicates significant differences from control $(P<$ 0.05)

In our experiments, the most sensitive parameter of the induced chlorophyll fluorescence, which showed significant changes in all of the polluted water samples collected from the Somes River, was the relative fluorescence decrease (Rfd), also known as the vitality index (Figure 2). The value of this index depends on the difference between the temporary maximal fluorescence yield in dark-adapted samples and the steady state fluorescence level in illuminated algal cultures. A reasonable explanation for this is that the steady state fluorescence level of the modulated chlorophyll fluorescence exhibits the widest range of 
changes upon stress conditions, as compared to the other measured parameters of fluorescence. The initial fluorescence of dark-adapted samples $\left(\mathrm{F}_{0}\right)$, related to the organization and energy transfer capacity of the light-harvesting antennae, as well as the maximal fluorescence $(\mathrm{Fm})$ related to the activity of electron acceptors of photosystem II, showed only small decreases upon contact of the alga with polluted water samples $\left(\mathrm{F}_{0}\right.$ decreased from an average of 121 relative units in the control to the average of 112 relative units in the water samples from the Baia Mare area, and similar degree of variation was registered for Fm). This concludes that these largely used fluorescence parameters are not suitable for indication of stress conditions exerted by the water samples collected from the Somes River. The effective quantum use efficiency of photosynthesis $(\Phi)$, reflecting the final photochemical yield of light absorption after dissipative processes, exhibited a very similar tendency with the $\mathrm{Fv} / \mathrm{Fm}$ ratio (significant decrease only in the presence of heavy metal pollution), so it also can be used as stress indicator only when severe heavy metal pollution of water occurs, but it is not useful when water is loaded with organic substances (data not shown). We mention that different parameters of chlorophyll fluorescence are also very sensitive to water pollution with herbicides that inhibit photosynthesis, but this was not the case of the water samples that we used in the experiments (Geoffroy et al., 2002; Cordos et al., 2003).

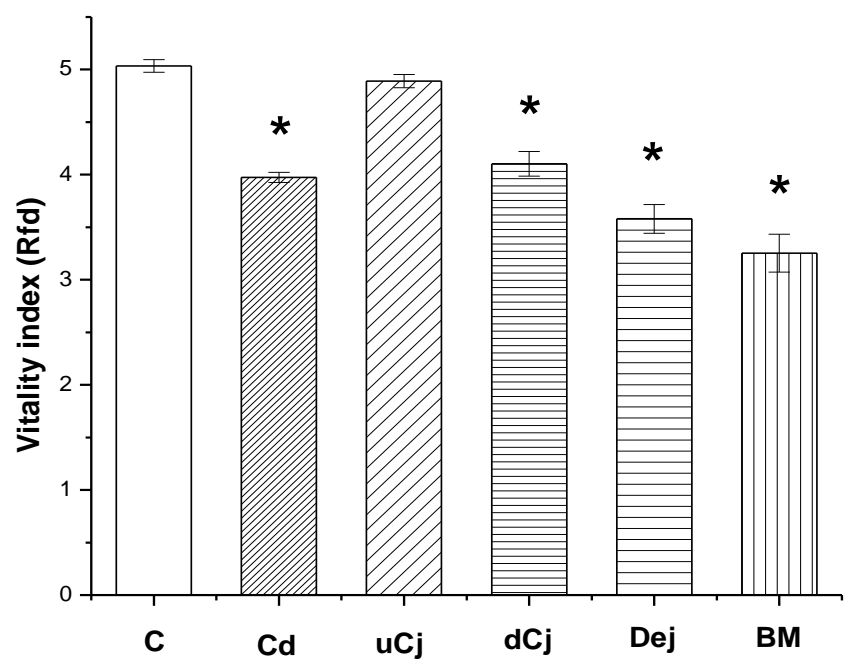

Figure (2): Vitality index deduced from chlorophyll fluorescence parameters in Scenedesmus opoliensis exposed to polluted water samples. C - control; Cd - $25 \mu \mathrm{M}$ $\mathrm{CdCl}_{2}$ in the nutrient medium; $\mathbf{u C j}$ - water from Somes River upstream Cluj city; $\mathrm{dCj}$ - water from downstream Cluj city; Dej - Somes water from the town of Dej; BM - water of Somes River from the Baia Mare region. Bars represent standard errors from means $(n=5)$, asterisk indicates significant differences from control $(P<$ 0.05) 
In relation with photosynthesis of algae, the photosynthetic pigment content of chloroplasts may indicate stress conditions caused not only by inadequate conditions of illumination, but also by chemicals that interfere with synthesis and degradation of pigment molecules. The pollutants present in the water samples taken from Somes River caused in the alga Scenedesmus opoliensis only moderate decreases in the absolute amount of chlorophyll $a$ and chlorophyll $b$, and moderate increases in the total carotenoid pigments, expressed on a dry weight basis. Because decrease of chlorophyll $a$ was proportional with that of chlorophyll $b$, the chlorophyll $a / b$ ratio did not change significantly under constant illumination. The only parameter that showed sensitive changes in polluted water samples, as compared to the control, was the molar ratio between the total chlorophyll and carotenoid content of algal cells (Figure 3). This is due to the fact that decreases in chlorophyll content are accompanied by increases in the amount of protective carotenoid pigments. Previous studies have shown that whenever the photochemical reactions of photosynthesis are impaired by adverse environmental factors, the chlorophylls are protected against photooxidative damage by an increased number of carotenoids (especially xanthophylls), that efficiently dissipate the excess amount of energy which was absorbed but cannot be used in carbon assimilation (Fodorpataki and Papp, 2000; Perales-Vela et al., 2007).

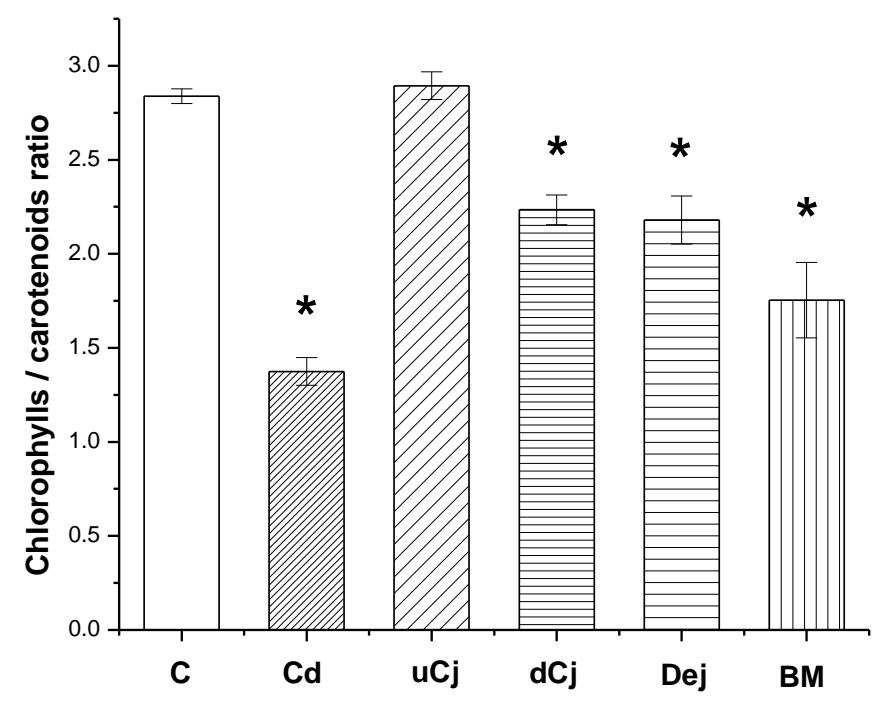

Figure (3): Chlorophylls to carotenoids ratio in Scenedesmus opoliensis exposed to polluted water samples. $\mathrm{C}$ - control; $\mathrm{Cd}-25 \mu \mathrm{M} \mathrm{CdCl}_{2}$ in the nutrient medium; $\mathbf{u C j}$ - water from Somes River upstream Cluj city; $\mathbf{d C j}$ - water from downstream Cluj city; Dej - Somes water from the town of Dej; BM - water of Somes River from the

Baia Mare region. Bars represent standard errors from means $(n=5)$, asterisk indicates significant differences from control $(P<0.05)$ 
Oxygen evolution of illuminated algal cells is also related to net photosynthetic efficiency under the prevailing environmental conditions, and a decreased oxygen production is usually due to inhibition of light reaction of photosynthesis by stress factors, or to an enhanced photorespiration that reduces the efficiency of biomass production. Upon exposure to polluted water samples from the Somes River, as well as in the presence of $25 \mu \mathrm{M}$ cadmium in the nutrient medium, the net oxygen production of algal populations (kept in constant illumination and at constant temperature) decreased moderately, but in a statistically significant degree. The most severe inhibition of photosynthetic oxygen evolution was registered in the presence of cadmium and in the polluted water collected from the Baia Mare mining and ore-processing region (Figure 4). Our results are in agreement with other studies that revealed the impairment of both photosynthetic and respiratory oxygen production in freshwater green algae exposed to known concentrations of specific heavy metals and organic pollutants, especially pesticides (Li et al., 2005; Perales-Vela et al., 2007; Prado et al., 2009).

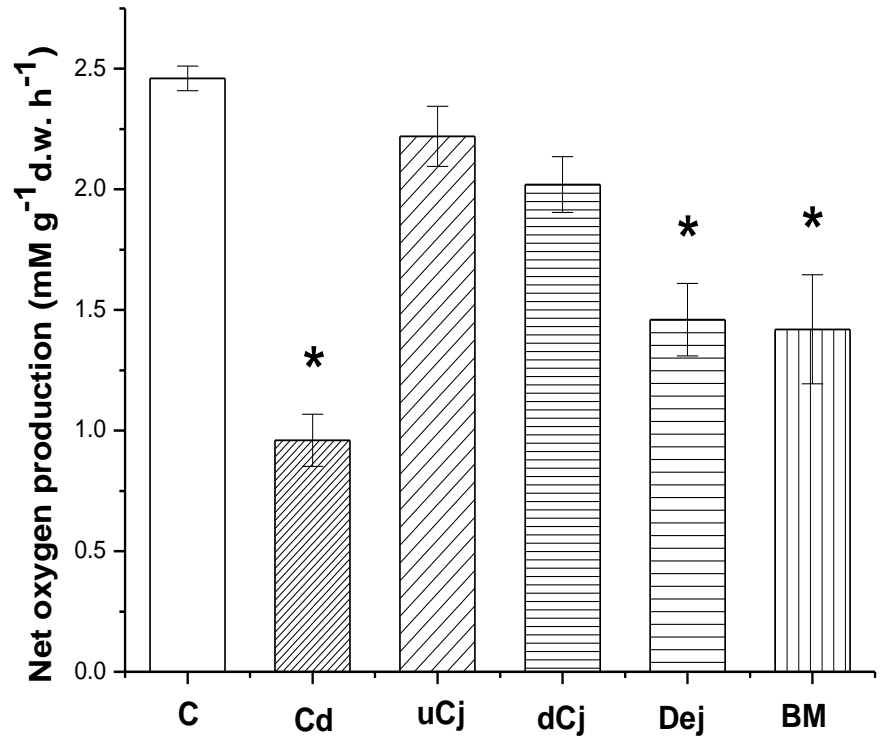

Figure (4): Oxygen production of illuminated Scenedesmus opoliensis exposed to polluted water samples. $\mathrm{C}$ - control; $\mathrm{Cd}-25 \mu \mathrm{M} \mathrm{CdCl}_{2}$ in the nutrient medium; $\mathbf{u C j}$ - water from Somes River upstream Cluj city; $\mathbf{d C j}$ - water from downstream Cluj city; Dej - Somes water from the town of Dej; BM - water of Somes River from the Baia Mare region; d.w. - dry weight. Bars represent standard errors from means (n $=5)$, asterisk indicates significant differences from control $(P<0.05)$

Reproductive capacity of algae is a relevant endpoint of acclimation to adverse conditions, and reflects how the populations cope with stress factors. From the different parameters that reflect growth and developmental dynamics of algal populations, the variation of cell density was found to be the best indicator of disturbances caused by water pollution along the sectors of the Somes River. 
The presence of household and industrial pollutants carried by the river downstream to the cities of Cluj and Dej delayed the growth of algal populations, but the most obvious inhibition of cell divisions was observed in the water of Baia Mare region, loaded with heavy metals. This inhibition was similar with the one registered in the presence of micromolar amounts of cadmium in the culture medium (Figure 5). Variations in cell density were more pronounced than decreases in the final dry biomass of algal populations grown in all of the polluted water samples, thereby in the case of this alga cell density is a more sensitive indicator of adverse influence of water pollution than biomass production. This is in agreement with findings of Rievie $\boldsymbol{e t}$ al. (2010), who concluded that in algal assemblages used for large river monitoring, phytoplankton cell density is the best indicator of water quality, and "absolute algal metrics have stronger relationships to water quality and stressors than relative (percentage-based) metrics".

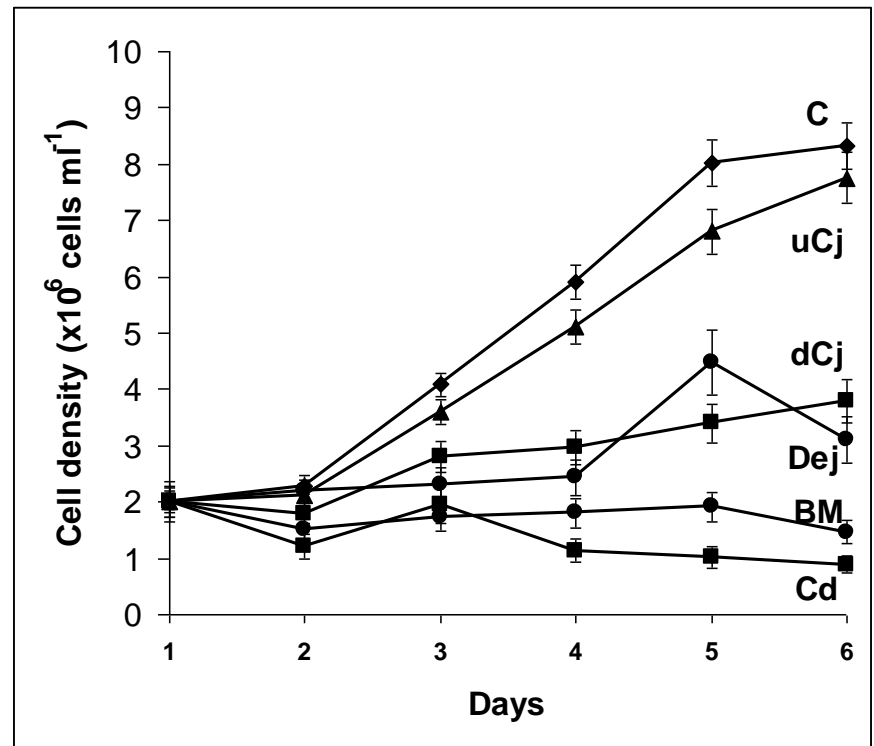

Figure (5): Dynamics of cell density in cultures of Scenedesmus opoliensis exposed to polluted water samples. $\mathrm{C}$ - control; $\mathrm{Cd}-25 \mu \mathrm{M} \mathrm{CdCl}_{2}$ in the nutrient medium; $\mathbf{u C j}$ - water from Somes River upstream Cluj city; $\mathbf{d C j}$ - water from downstream Cluj city; Dej - Somes water from the town of Dej; BM - water of Somes River from the Baia Mare region. Bars represent standard errors from means $(n=5)$.

Many environmental stress factors induce in algal cells an increased generation of dangerous reactive oxygen species, which in their turn amplify the stress effect by damaging membrane structure and permeability, by impairing enzyme activities and gene expression, causing metabolic disturbances and premature senescence. One of the first signs of oxidative stress is peroxidation of unsaturated fatty acids in membrane lipids, which results in damaged membrane structure and in formation of mobile peroxidation products (especially malondialdehyde) that are very toxic and amplify the oxidative damage. This is 
why any increase in lipid peroxidation is an early indicator of stress condition associated with enhanced generation of reactive oxygen species (hydrogen peroxide, superoxide and hydroxyl radicals, singlet oxygen). Because many pollutants initiate the overproduction of reactive oxygen species (especially during the photochemical reactions when absorbed light energy saturates the photosynthetic capacity), lipid peroxidation is a general consequence of metabolic disturbances. From the biochemical parameters determined by us in the alga Scenedesmus opoliensis, the increment of membrane lipid peroxidation was one of the most sensitive indicators of stress condition imposed by the presence of pollutants in the water samples taken from the different sectors of the Somes River. The highest lipid peroxidation was found in the algal cultures growing in the water taken from the Baia Mare mining region and from the industrially polluted water from Dej, but the mainly organic pollutants of the water downstream to the city of Cluj also induced oxidative membrane damage. The water collected upstream to Cluj did not cause a higher degree of lipid peroxidation than the one recorded in the control (Figure 6). Different authors also concluded that increment of lipid peroxidation is a good molecular marker for oxidative stress induced by high amounts of heavy metals or by herbicides such as paraquat, and it is even suitable to discriminate between ecotypes of the same algal species with different degrees of tolerance to polluting chemicals (Gorbi $\boldsymbol{e t}$ al., 2006; Vallotton et al., 2008).

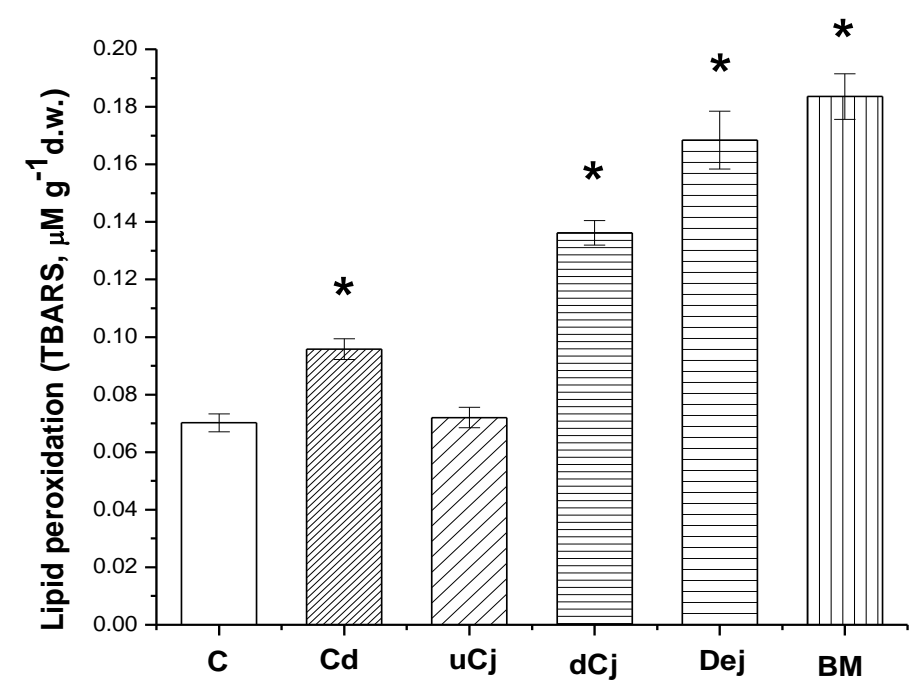

Figure (6): Membrane lipid peroxidation in Scenedesmus opoliensis exposed to polluted water samples. $\mathrm{C}$ - control; $\mathrm{Cd}-25 \mu \mathrm{M} \mathrm{CdCl}_{2}$ in the nutrient medium; $\mathbf{u C j}$ - water from Somes River upstream Cluj city; $\mathbf{d C j}$ - water from downstream Cluj city; Dej - Somes water from the town of Dej; BM - water of Somes River from the

Baia Mare region; d.w. - dry weight; TBARS - thiobarbituric acid-reactive substances. Bars represent standard errors from means $(n=5)$, asterisk indicates significant differences from control $(P<0.05)$ 
One of the most frequent reactive oxygen derivatives that accumulate in algal cells upon exposure to stress factors is hydrogen peroxide. It is mainly generated in the pseudocyclic electron transport of the light phase of photosynthesis (in the Mehler reaction), but it may also be a byproduct of the impaired mitochondrial respiration or of the defense reactions initiated in the damaged cell wall and peroxisomes. Because of its high mobility, it spreads quickly in the different compartments of algal cells. In low concentrations it plays a role in the chemical signaling of oxidative stress, but it becomes a powerful enzyme inhibitor if it accumulates in high concentrations. Its amount in algal cells indicates the degree of oxidative stress caused by adverse environmental conditions and the efficiency of the antioxidative defense system of the cells. Water pollution in the Cluj and Dej sectors of the Somes River (caused mainly by organic compounds) induced only a moderate increase in the hydrogen peroxide production of algal cells, while water pollution caused mainly by heavy metals in the Baia Mare region resulted in a considerable enhancement of hydrogen peroxide generation (Figure 7).

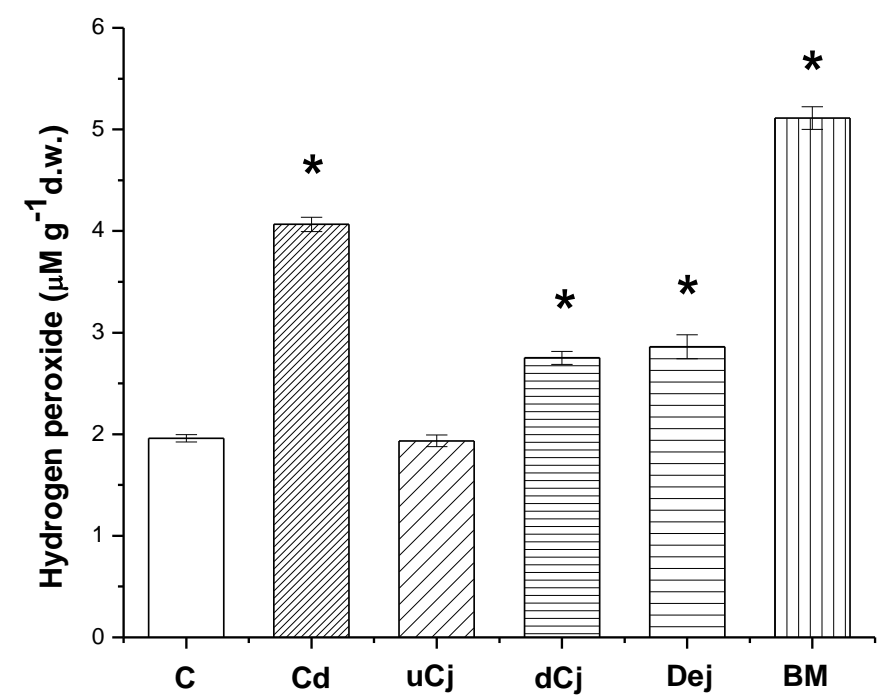

Figure (7): Concentration of hydrogen peroxide in Scenedesmus opoliensis exposed to polluted water samples. $\mathrm{C}$ - control; $\mathrm{Cd}-25 \mu \mathrm{M} \mathrm{CdCl}_{2}$ in the nutrient medium; $\mathbf{u C j}$ - water from Somes River upstream Cluj city; $\mathbf{d C j}$ - water from downstream Cluj city; Dej - Somes water from the town of Dej; BM - water of Somes River from the Baia Mare region; d.w. - dry weight. Bars represent standard errors from means ( $n$ $=5)$, asterisk indicates significant differences from control $(P<0.05)$

Because many environmental stress factors induce oxidative damage in the metabolism of algal cells, the antioxidative protective system plays an important role in tolerance of adverse conditions. This system has both nonenzymatic and enzymatic components. The main non-enzymatic protective 
molecules, which have a pronounced reducing capacity, are ascorbic acid (vitamin C), tocopherol (vitamin E), glutathione, flavones and carotenoids. In algae the most abundant of these is ascorbic acid. Under our experimental conditions its concentration increased slightly, but significantly in algal cells when they were exposed to the mixture of pollutants present in the water samples collected from the Baia Mare and Dej sectors of the Somes River (Figure 8). The results suggest that the total amount of ascorbic acid is not a very good indicator of water pollution, and as a future prospect it would be advisable to distinguish between the reduced and the oxidized form of the molecule, and to observe the possible variations in the ratio between the reduced ascorbic acid and the oxidized dehydroascorbic acid, even if the total amount of the vitamin will not vary significantly. In other cases, especially when different heavy metals, high salt concentrations, excessive photon flux densities or low temperatures induced a severe oxidative damage, the amount of ascorbic acid exhibited a serious increment in tolerant species that became hardened during exposure to adverse environmental conditions (Madhava Rao and Sresty, 2000; Celekli et al., 2008; Fodorpataki et al., 2008).

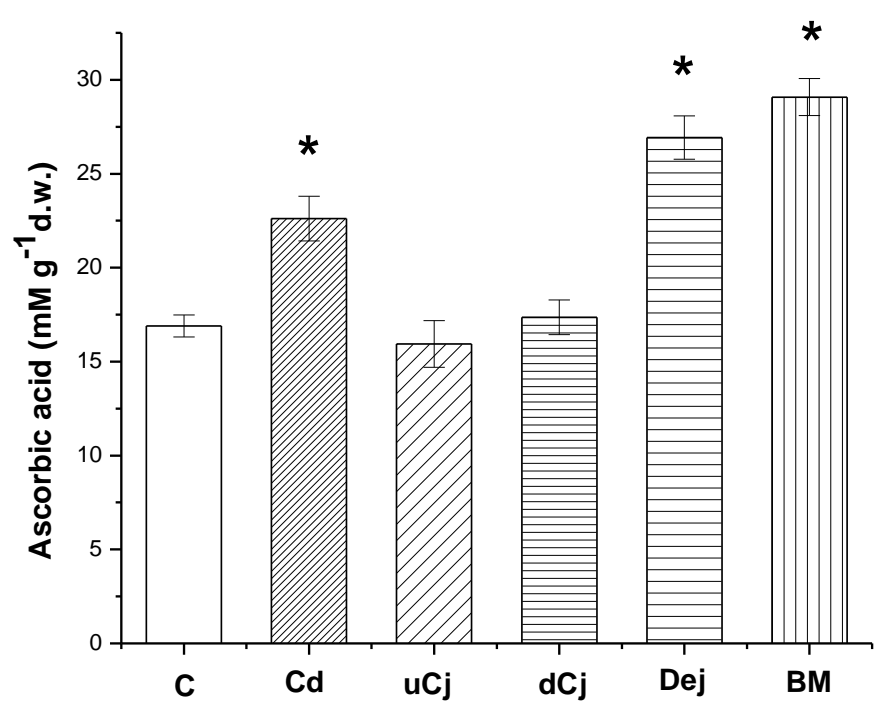

Figure (8): Ascorbic acid content of Scenedesmus opoliensis exposed to polluted water samples. $\mathrm{C}$ - control; $\mathrm{Cd}-25 \mu \mathrm{M} \mathrm{CdCl}$ in the nutrient medium; $\mathbf{u C j}$ - water from Somes River upstream Cluj city; $\mathrm{dCj}$ - water from downstream Cluj city; Dej Somes water from the town of Dej; BM - water of Somes River from the Baia Mare region; d.w. - dry weight. Bars represent standard errors from means $(n=5)$, asterisk indicates significant differences from control $(P<0.05)$ 
The enzymatic components of the antioxidative protective system include ascorbate peroxidase, superoxide dismutase, catalase, peroxiredoxins, glutathione reductase, monodehydro-ascorbate reductase etc. Because hydrogen peroxide and superoxide radicals are the most frequent reactive oxygen species that are generated in algae under oxidative stress, the enzymatic activities of ascorbate peroxidase and superoxide dismutase are relevant for monitoring the efficiency of the antioxidative protection. In chlorophycean algae catalase activity is weak or it cannot be detected at all, because these algae do not oxidize glycolate and do not produce hydrogen peroxide in the peroxisomes during the photorespiratory carbon oxidation cycle. This is in relation with the fact that when these algae perform an active photorespiration, they secrete appreciable amounts of glycolate, instead of oxidizing it into glyoxylate and hydrogen peroxide, in a reaction which in higher plants is catalized by peroxisomal glycolate oxidase (Stabenau and Winkler, 2005). In the alga Scenedesmus opoliensis exposed to polluted water samples, a very high ascorbate peroxidase activity was registered when only a moderate increment of the hydrogen peroxide concentration occurred in the cells. When pollution induced accumulation of high amounts of hydrogen peroxide (e.g. in water samples from the Baia Mare region), ascorbate peroxidase activity was inhibited (Figure 9). The most possible explanation for this finding is that the enzyme decomposes efficiently (with contribution of reduced ascorbic acid) the smaller amounts of hydrogen peroxide, but it becomes inhibited by high concentrations of hydrogen peroxide (accumulated in lack of an efficient catalase activity). Variations of the superoxide dismutase activity were very similar with those of ascorbate peroxidase, but they manifested with a lower intensity (data not shown), this is why the dynamics of ascorbate peroxidase is a more sensitive indicator of stress conditions caused by exposure of Scenedesmus opoliensis to polluted water. Different changes in the activity of ascorbate peroxidase were reported for Scenedesmus obliquus exposed to water pollution with different herbicides (Geoffroy $\boldsymbol{e t}$ al., 2002), and in the same algal species markedly high levels of superoxide dismutase activity were correlated with a combined effect of aromatic hydrocarbons, cadmium ions and triazine-type herbicides in polluted water samples (Zbigniew and Wojciech, 2006). Li and coworkers (2005) have found that superoxide dismutase activity in Scenedesmus obliquus is a sensitive biomarker for water pollution with synthetic pyrethroids. Further investigations are needed to elucidate the changes in these enzyme activities during exposure of different algae to various environmental stress conditions. 


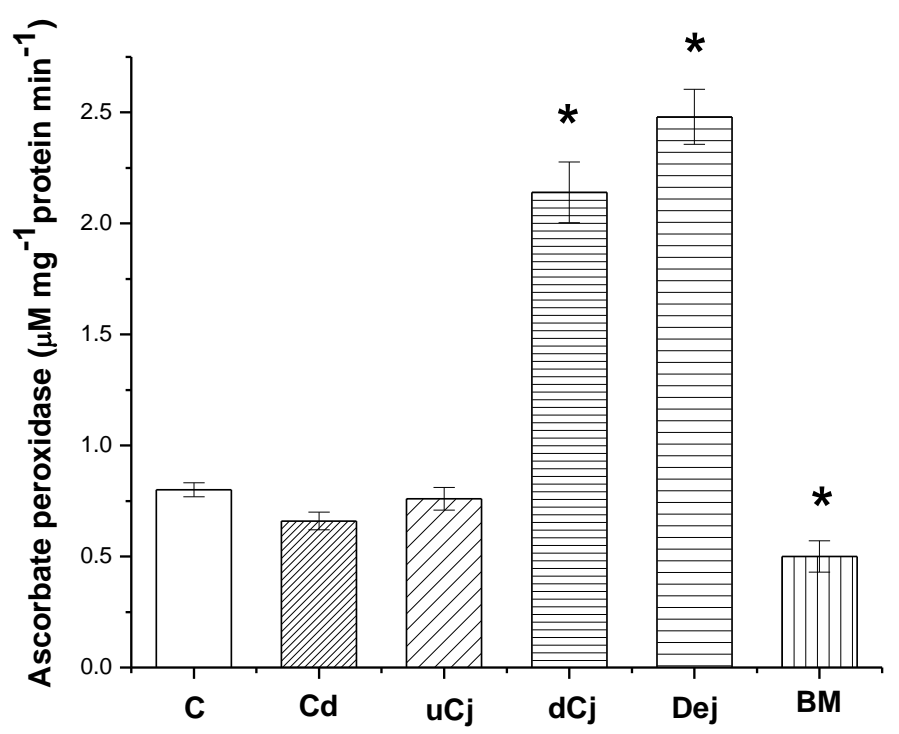

Figure( 9): Ascorbate peroxidase activity in Scenedesmus opoliensis exposed to polluted water samples. $\mathrm{C}$ - control; $\mathrm{Cd}-25 \mu \mathrm{M} \mathrm{CdCl}_{2}$ in the nutrient medium; $\mathbf{u C j}$ - water from Somes River upstream Cluj city; $\mathbf{d C j}$ - water from downstream Cluj city; Dej - Somes water from the town of Dej; BM - water of Somes River from the Baia Mare region. Bars represent standard errors from means $(n=5)$, asterisk indicates significant differences from control $(P<0.05)$

In conclusion, due to the pronounced metabolic plasticity of the green microalga Scenedesmus opoliensis, its tolerance to stress conditions can be revealed through statistically significant changes in many physiological processes and in their specific products. Enzymatic activity of ascorbate peroxidase, membrane lipid peroxidation and vitality index derived from induced chlorophyll fluorescence, are sensitive indicators of metabolic disturbances caused by water pollution with household and industrial organic compounds, as well as with heavy metals from mining activities. Changes in cell density of algal populations are better indicators of water pollution than net biomass production. Decreases in the potential quantum efficiency of photosynthesis (reflected by the $\mathrm{Fv} / \mathrm{Fm}$ fluorescence ratio) and in net oxygen production indicate mainly heavy metal stress. Photosynthetic pigment content of this alga is not a good biochemical marker of water pollution, but the molar ratio between the total amount of chlorophylls and carotenoids decreases significantly as the environmental stress impairs the algal metabolism. Further investigations may reveal other useful physiological and biochemical markers of water pollution on algae used in standardized single-species test systems, and may contribute to a better 
knowledge of defense mechanisms during acclimation to changed environmental conditions.

\section{Acknowledgement}

This work was carried out with the financial support from the research project MENER P-CD PC-D06-PT25-293, as well as from the Sectorial Operational Program "Human Resources Development, Contract POSDRU 6/1.5/S/3 - Doctoral studies: through science towards society", and by CNCSISUEFISCSU project PN II-RU TE 306/2010.

We express our gratitude to Dr. Endre Sarkany-Kiss for sharing with us his experience in choosing the appropriate sampling sites and collecting the water samples.

\section{References}

Baryla, A.; Laborde, C.; Montillet, J.-L.; Triantaphylides, C. and Chagvardieff, P. (2000). Evaluation od lipid peroxidation as a toxicity bioassay for plants exposed to copper. Environ. Pollut., 109: 131-135.

Celekli, A.; Balci, M. and Bozkurt, H. (2008). Modelling of Scenedesmus obliquus; function of nutrients with modified Gompertz model. Biores. Techn., 99:8742-8747.

Cordos, E.; Ratiu, R.; Roman, C.; Ponta, M.; Frentiu, T.; SarkanyKiss, A.; Fodorpataki, L.; Macalik, K.; McCormick, C. and Weiss, D. (2003). Characterization of the rivers system in the mining and industrial area of Baia Mare, Romania. Eur. J. Min. Proc. Environ. Prot., 3(3): 324-335.

Dragos, N.; Peterfi, L. S.; Momeu, L. and Popescu, C. (1997). An introduction to the algae and culture collection of algae at the Institute of Biological Research Cluj-Napoca, Cluj University Press, p. 197.

Fodorpataki, L.; Bartha, Cs. and Keresztes, Zs. Gy. (2009). Stressphysiological reactions of the green alga Scenedesmus opoliensis to water pollution with herbicides. Ann. Univ. Or., Fasc. Biol., 16(1): 51-56.

Fodorpataki, L. and Bartha, L. (2008). Differential sensitivity of the photosynthetic apparatus of a freshwater green alga and of duckweed exposed to salinity and heavy metal stress. In: Allen, J. F., Gantt, E., Golbeck, J. H. and Osmond, B. (Eds.): 
Photosynthesis: Energy from the Sun, Springer, Dordrecht, pp. 1451-1454.

Fodorpataki, L.; Marton, A. and Csorba, T. (2001). Stress-physiological investigation of algal cell cultures in polluted media. Contrib. Bot., 36: 101-108.

Fodorpataki, L. and Papp, J. (2000). Studies concerning the physiology of microalgal communities isolated from natural habitats. Contrib. Bot., 35: 121-130.

Geoffroy, L.; Teisseire, H.; Couderchet, M. and Vernet, G. (2002). Effect of oxyfluorfen and diuron alone and in mixture on antioxidative enzymes of Scenedesmus obliquus. Pestic. Biochem. Physiol., 72: 178-185.

Gorbi, G.; Torricelli, E.; Pawlik-Skowronska, B.; Toppi, L. S.; Zanni, C. and Corradi, M. G. (2006). Differential responses to Cr(VI)induced oxidative stress between Cr-tolerant and wild-type strains of Scenedesmus acutus (Chlorophyceae). Aquat. Toxic., 79: 132139.

Kaplan, D. (2007). Water pollution and bioremediation by microalgae. In: Richmond, A. (Ed.), Handbook of Microalgal Culture. Blackwell, Oxford, pp. 439-447.

Lee, Y.-K. and Shen, H. (2007). Basic culturing techniques. In: Richmond, A. (Ed.), Handbook of Microalgal Culture. Blackwell, Oxford, pp. 40-56.

Li, X.; Ping, X.; Xiumei, S.; Zhenbin, W. and Liqiang, X. (2005). Toxicity of cypermethrin on growth, pigments, and superoxide dismutase of Scenedesmus obliquus. Ecotox. Environ. Safety, 60: 188-192.

Lichtenthaler, H. K. and Wellburn, A. R. (1983). Determination of total carotenoids and chlorophylls $a$ and $b$ of leaf extracts in different solvents. Biochem. Soc. Trans., 11: 591-592.

Lombardi, A. T.; Hidalgo, T. M. R. and Vieira, A. A. H. (2005). Copper complexing properties of dissolved organic materials exuded by the freshwater microalgae Scenedesmus acuminatus (Chlorophyceae). Chemosphere, 60: 453-459.

Madhava Rao, K. V. and Sresty, T. V. S. (2000). Antioxidative parameters in the seedlings of pigeonpea in response to $\mathrm{Zn}$ and $\mathrm{Ni}$ stresses. Plant Sci., 157: 113-128.

Mallich, N. and Mohn, F. H. (2003). Use of chlorophyll fluorescence in metal-stress research: a case study with the green microalga Scenedesmus. Ecotox. Environ. Safety, 55: 64-69. 
Perales-Vela, H. V.; Gonzales-Moreno, S.; Montes-Horcasitas, C. and Canizares-Villanueva, R. O. (2007). Growth, photosynthetic and respiratory responses to sub-lethal copper concentrations in Scenedesmus incrassatulus (Chlorophyceae). Chemosphere, 67: 2274-2281.

Prado, R.; Garcia, R.; Rioboo, C.; Herrero, C.; Abalde, J. and Cid, A. (2009). Comparison of the sensitivity of different toxicity test endpoints in a microalga exposed to the herbicide paraquat. Environ. Internatl., 35: 240-247.

Reavie, E. D.; Jicha, T. M.; Angradi, T. R.; Bolgrien, D. W. and Hill, B. H. (2010). Algal assemblages for large river monitoring: comparison among biovolume, absolute and relative abundance metrics. Ecol. Indic., 10: 167-177.

Rodriguez-Garcia, I. and Guil-Guerrero, J. L. (2008). Evaluation of the antioxidant activity of three microalgal species for use as dietary supplements and in the preservation of foods. Food Chem., 108: 1023-1026.

Sarkany-Kiss, A. and Hamar, J. (1999). The Somes/Szamos River Valley, Tiscia

Stabenau, H. and Winkler, U. (2005). Glycolate metabolism in green algae. Physiol. Plant., 123: 235-245.

Vallotton, N.; Moser, D.; Eggen, R. I. L.; Junghans, M. and Chevre, N. (2008). S-metolachlor pulse exposure on the alga Scenedesmus vacuolatus: effects during exposure and the subsequent recovery. Chemosphere, 73: 395-400.

Zavaleta-Mancera, H. A.; Lopez-Delgado, H.; Loza-Tavera, H.; MoraHerrera, M.; Trevilla-Garcia, C.; Vargas-Suarez, M. and Ougham, H. (2007). Cytokinin promotes catalase and ascorbate peroxidase activities and preserves the chloroplast integrity during dark-senescence. J. Plant Physiol., 164: 1572-1582.

Zbigniew, T. and Wojciech, P. (2006). Individual and combined effect of anthracene, cadmium, and chloridazone on growth and activity of SOD izoformes in three Scenedesmus species. Ecotox. Environ. Safety, 65: 323-331.

Zhang, E.; Wang, B.; Wang, Q.; Zhang, S. and Zhao, B. (2008). Ammonia-nitrogen and orthophosphate removal by immobilized Scenedesmus sp. isolated from municipal wastewater for potential use in tertiary treatment. Biores. Techn., 99: 3787-3793. 


\section{مؤشرات حيوية لتلوث المياه فى تهر سوميس باستخدام خواص كيموحيوية

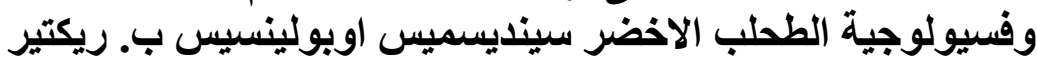 \\ لآسلو فودوربوتكى -جولت جى. كريستيس - تثبا بأرتا - سوبولاش بارنا \\ قسم الاحياء جامعة باباش - بوياى - تسلوى نابوتسا - ش كوجالنيتسيانى}

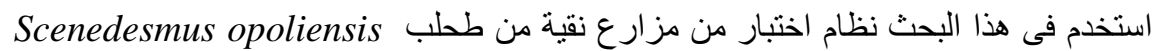

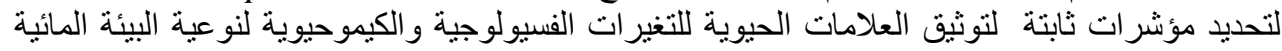

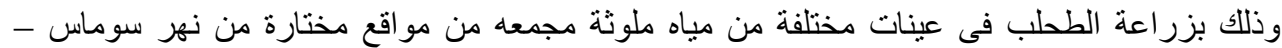

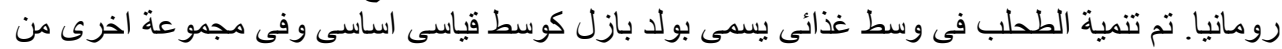

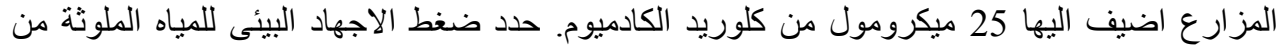

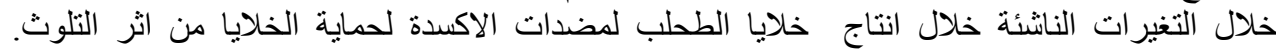

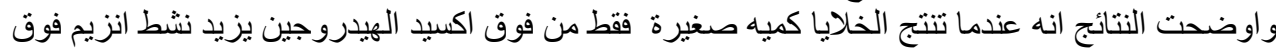

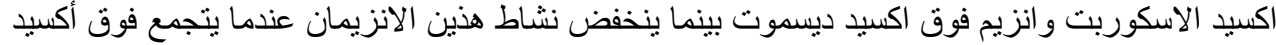

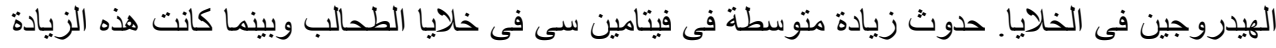

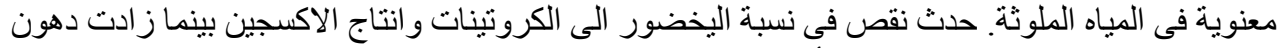

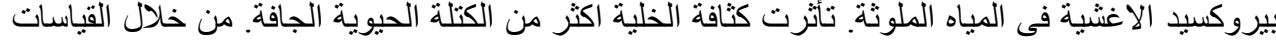

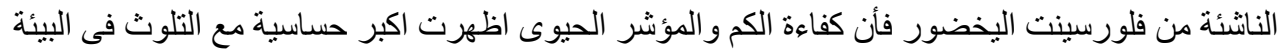

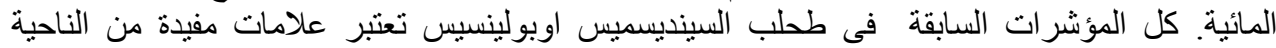
الفسيويوجية و الكيمو حيوية لتعين تلوث المئة المياه. 